http://dx.doi.org/10.11646/phytotaxa.158.3.8

\title{
A systematic classification of Ephedraceae: living and fossil
}

\author{
YONG YANG \\ State Key Laboratory of Systematic and Evolutionary Botany, Institute of Botany, the Chinese Academy of Sciences, 20 Nanxincun, \\ Xiangshan, Beijing 100093, China. Email: ephedra@ibcas.ac.cn
}

\begin{abstract}
A number of Ephedroid macrofossils have been described from the Early Cretaceous in the last decade, indicating huge diversity of early Ephedraceae. However, relationships among these fossils and modern Ephedra remain ambiguous. This study proposes a new systematic classification of the family at the generic level based on the reduction and sterilization evolutionary hypothesis of female reproductive organs. Two subfamilies and two tribes are described as new to science. In this new classification, the family Ephedraceae consists of two subfamilies: Siphonospermoideae Y. Yang subfam. nov. and Ephedroideae Y. Yang subfam. nov, and the latter subfamily is divided again into two tribes: Liaoxieae Y. Yang trib. nov. and Ephedreae Y. Yang trib. nov. Ten genera are included in the new classification, and two genera are listed as doubtful due to their taxonomic characters being insufficient to place them in Ephedraceae.
\end{abstract}

Key words: Classification, Ephedraceae, female cone, morphology, reduction and sterilization hypothesis, systematics

\section{Background}

The modern Ephedraceae of the Gnetales consist of only 1 living genus Ephedra L. (1753: 1040) and ca. 55 species that are widely distributed through the North Temperate Zone and high mountains of S America (Stapf 1889; Florin 1933; Gifford \& Foster 1989; Stevenson 1993; Price 1996; Caveney et al. 2001; Yang 2007a).

Due to extensive extinction in the geological past, modern Ephedraceae possess a set of morphological characters disjunct from the other two monotypic families of the Gnetales (Gnetaceae and Welwitschiaceae) as well as from other living seed plants including cycads, Ginkgo, conifers, and angiosperms (Pearson 1929; Cutler 1939; Martens 1971; Fu et al. 1999). Plants of this family have branches/twigs including nodes and internodes, the node is enlarged, and the internode is longitudinally furrowed. Leaves usually bear 2 (-4) parallel veins, and are opposite and decussate or ternately whorled; they are free and linear in Early Cretaceous fossils and a few extant species, but fused into a sheath at a node in most living species. Female cones of extant Ephedra are compound, and have a few pairs/whorls of bracts, but only the uppermost pair/whorl of bracts enclose 1-3 seeds. The bracts are fleshy, coriaceous, or membranous when the cone is mature. The characteristic female reproductive unit bears an outer envelope and an inner integument, the integument is elongated into a micropylar tube passing through the apical opening of the outer envelope. Male cones have many whorls/pairs of bracts, each bract usually subtends an axillary male reproductive unit; the male reproductive unit consists of a pair of bracteoles enclosing an inner antherophore; each antherophore has 3-12 stalked or sessile bilocular synangia at the tip.

Evolutionary inference of such an ancient family based on molecular systematic studies is not convincing by sampling only the living representatives. The relationships of modern Ephedra show strong geographical structure, and molecular clock analysis dates the origin of Ephedra at ca. 32 Mya (e.g. Huang et al. 2005; Ickert-Bond et al. 2004; Ickert-Bond et al. 2009). This age is far more recent than an Early Cretaceous origin as evidenced by macrofossils (Yang et al. 2005; Rydin et al. 2006a; Wang \& Zheng 2010; Yang \& Wang 2013).

Palaeobotanical evidence has been providing past links for living groups of plants. Fortunately, many Ephedroid macrofossil taxa bearing evolutionary significance were described from the Early Cretaceous worldwide in the last two decades, e.g. Asia (Guo \& Wu 2000; Sun et al. 2001; Tao \& Yang 2003; Yang et al. 2005; Rydin et al. 2006b; Liu et al. 2008; Krassilov 2009; Rydin \& Friis 2010; Wang \& Zheng 2010; Yang 2010; Yang \& 
2.2.2 Beipiaoa Dilcher et al. in Sun et al., Early Angiosperms and Associated Plants from Western Liaoning, China, 151 (2001)—T.: B. spinosa Dilcher et al.

3 fossil species from the Early Cretaceous of western Liaoning, China. Krassilov (2009) thought reproductive organs of Beipiaoa spinosa Dilcher et al. are cupules of Eoantha ornata Krassilov (1999: 113), but the morphology of the two species looks different each other. There are many collections of Beipiaoa in the Yixian Formation and additional studies are still needed.

2.2.3 Erenia Krassilov in Palaeontogr. Abt B 181: 33 (1982)-T.: E. stenoptera Krassilov

Syn.: Callianthus Wang et Zheng in J. Int. Pl. Biol. 51: 800 (2009) syn. nov. -T.: C. dilae Wang et Zheng

1 fossil species from the Early Cretaceous of Mongolia and western Liaoning, China.

2.2.4 Amphiephedra Miki in Bull. Mukogawa Women's Univ., Nat. Sci. 12: S21 (1964)—T.: A. rhamnoides Miki

1 fossil species from the Early Cretaceous of western Liaoning, China.

2.2.5 Alloephedra Tao et Yang in Acta Palaeontol. Sin. 42: 212 (2003)-T.: A. xingxueii J.R. Tao et Y. Yang

1 fossil species from the Dalazi Formation (Aptian-Albian, Early Cretaceous) of Jilin Province, China

2.2.6 Ephedra L., Sp. Pl.: 1040 (1753)—T.: E. distachya L.

Syn.: Baicarpus Gang Han et al., Acta Geol. Sin. 87: 917 (2013) syn. nov.

Ca. 55 living species widely distributed in the North Temperate Zone, and Temperate South America, and 4 fossil species among which 3 species are from the Early Cretaceous of western Liaoning of China, and 1 species from the Baqueró Group, Anfiteatro de Ticó Formation (Aptian, Early Cretaceous) at Estancia Bajo Grande, Santa Cruz Province, Argentina.

Unplaced genera

Leongathia Krassilov et al. in Alcheringa 22: 127 (1998) - T.: Leongathia elegans Krassilov et al. (1998: 127) 1 fossil species of a vegetative shoot from the Lower Cretaceous of Koonwarra Fossil Bed, Victoria, Australia.

Ephedrispermum Rydin et al. in Ann. Bot. 98: 129 (2006)-T.: Ephedrispermum lusitanicum Rydin et al. (2006: 129)

1 mesofossil species of seeds having in situ pollen from Calvaria Member, Figueira da Foz Formation (late Aptian or early Albian) at Buarcos, North of Figueira da Foz of Portugal. Friis et al. (2009) ascribed this genus into the BEG clade, but its position in the new system of the family Ephedraceae can not be determined since lacking characters of female cones.

\section{Acknowledgements}

I am grateful to John McNeill for valuable suggestions on both nomenclature and English. Thanks are also due to Qi Wang, Wenli Chen, and James L. Reveal for some of the literature. This work was supported by the National Natural Science Foundation of China [31270238, 30970177] and an initiative project from the Ministry of Science and Technology of the People's Republic of China.

\section{References}

Anderson, J.M. \& Anderson, M.H. (2003) Heyday of the Gymnosperms: Systematics and Diversity of the Late Triassic Molteno Fructifications. Strelitzia 15. Pretoria: National Botanical Institute. 398 p.

Anderson, J.M., Anderson, M.H. \& Cleal, C.J. (2007) Brief History of the Gymnosperms: Classification, Biodiversity, Phytogeography and Ecology. Strelitzia 20. Pretoria: National Botanical Institute. 280 p.

Ash, S.R. (1970) Dinophyton, a problematical new plant genus from the Upper Triassic of the south-western United States. Palaeontology 13: 646-663.

Cao, Z.-Y., Wu, S.-Q., Zhang, P.-A. \& Li, J.-R. (1998) Discovery of fossil monocotyledons from Yixian Formation, western Liaoning. Chinese Science Bulletin 43: 230-233.

http://dx.doi.org/10.1007/bf02898918 
Caveney, S., Charlet, D.A., Freitag, H., Maier-Stolte, M. \& Starratt, A.N. (2001) New observations on the secondary chemistry of world Ephedra (Ephedraceae). American Journal of Botany 88: 1199-1208. http://dx.doi.org/10.2307/3558330

Christenhusz, M.J.M., Reveal, J.L., Farjon, A., Gardner, M.F., Mill, R.R. \& Chase, M.W. (2011) A new classification and linear sequence of extant gymnosperms. Phytotaxa 19: 55-70.

Cladera, G., Fueyo, G.M.D., de Seoane, L.V. \& Archangelsky, S. (2007) Early Cretaceous riparian vegetation in Patagonia, Argentina. Revista del Museo Argentino de Ciencias Naturales, n.s. 9: 49-58.

Cutler, H.C. (1939) Monograph of the North American species of the genus Ephedra. Annals of the Missouri Botanical Garden 26: $373-429$. http://dx.doi.org/10.2307/2394299

Duan, S.-Y. (1997) [The oldest angiosperm - a tricarpous female reproductive fossil from western Liaoning Province, northeastern China]. Science in China Series D 27(6): 519-524. In Chinese

Duan, S.-Y. (1998) The oldest angiosperm - a tricarpous female reproductive fossil from western Liaoning Province, northeastern China. Science in China Series D 41: 14-20. http://dx.doi.org/10.1007/bf02932415

Dumortier, B.C.J. (1829) Analyse des familles des plantes, avec l'indication des principaux genres qui s'y rattachent. Tournay: Imprimerie de J. Casterman Ainé. 104 p. http://dx.doi.org/10.5962/bhl.title.443

Florin, R. (1933) Über einige neue oder wenig bekannte asiatische Ephedra-Arten der Sect. Pseudobaccatae Stapf. Kungl. Svenska Vetenskapsakademiens Handlingar serien 3 12: 264-289.

Friis, E.M., Crane, P.R. \& Pedersen, K.R. (2011) Early flowers and angiosperm evolution. Cambridge: Cambridge University Press. 585 p. http://dx.doi.org/10.3732/ajb.0800113

Friis, E.M., Pedersen, K.R. \& Crane, P.R. (2009) Early Cretaceous mesofossils from Portugal and eastern North America related to the Bennettitales-Erdtmanithecales-Gnetales group. American Journal of Botany 96: 252-283.

Fu, L.-G., Yu, Y.-F. \& Riedl, H. (1999) Ephedraceae. In Wu, Z.-Y. \& Raven, P.H., editors. Flora of China, volume 4. Beijing: Science Press \& St. Louis: Missouri Botanical Garden. pp. 97-101.

Gifford, E.M. \& Foster, A.S. (1989) Comparative morphology of vascular plants, third edition. New York: WH Freeman. 626 p.

Guo, S.-X. \& Wu, X.-W. (2000) Ephedrites from Latest Jurassic Yixian Formation in western Liaoning, Northeast China. Acta Palaeontologica Sinica 39: 81-91.

Han, G., Fu, X.-P., Liu, Z.-J. \& Wang, X. (2013) A new angiosperm genus from the Lower Cretaceous Yixian Formation, western Liaoning, China. Acta Geologica Sinica 87: 916-925. http://dx.doi.org/10.1111/1755-6724.12100

Huang, J.-L., Giannasi, D.E. \& Price, R.A. (2005) Phylogenetic relationships in Ephedra (Ephedraceae) inferred from chloroplast and nuclear DNA sequences. Molecular Phylogenetics and Evolution 35: 48-59. http://dx.doi.org/10.1016/j.ympev.2004.12.020

Ickert-Bond, S.M., Rydin, C. \& Renner, S.S. (2009) A fossil-calibrated relaxed clock for Ephedra indicates an Oligocene age for the divergence of Asian and New World clades and Miocene dispersal into South America. Journal of Systematics and Evolution 47: 444-456. http://dx.doi.org/10.1111/j.1759-6831.2009.00053.x

Ickert-Bond, S.M. \& Wojciechowski, M.F. (2004) Phylogenetic relationships in Ephedra (Gnetales): evidence from nuclear and chloroplast DNA sequence data. Systemaic Botany 29: 834-849. http://dx.doi.org/10.1600/0363644042451143

Kirpotenko, A.P. (1884) [Outline of the Natural Classification of Plants. Compiled after Eichler]. Očerk estestvennoj klassifikacii rastitel'nosti 7: 1-54. (in Russian).

Krassilov, V.A. (1982) Early Cretaceous flora of Mongolia. Palaeontographica Abteilung B-Palaophytologie 181: 1-43.

Krassilov, V.A. (1986) New floral structure from the Lower Cretaceous of Lake Baikal area. Review of Palaeobotany and Palynology 47: 9-16. http://dx.doi.org/10.1016/0034-6667(86)90003-5

Krassilov, V.A. \& Bugdaeva, E.V. (1988) Gnetalean plants in the Jurassic of Ust-Balej, East Siberia. Review of Palaeobotany and Palynology 53: 359-374. http://dx.doi.org/10.1016/0034-6667(88)90040-1

Krassilov, V.A. (2009) Diversity of Mesozoic gnetophytes and the first angiosperms. Paleontological Journal 43:1272-1280. http://dx.doi.org/10.1134/s0031030109100098

Krassilov, V.A. \& Bugdaeva, E.V. (1999) An angiosperm cradle community and new proangiosperm taxa. Acta Palaeobotanica Supplement 2: 111-127.

Krassilov, V.A., Dilcher, D.L. \& Douglas, J.G. (1998). New ephedroid plant from the Lower Cretaceous Koonwarra fossil bed, Victoria, Australia. Alcheringa 22: 123-133. http://dx.doi.org/10.1080/03115519808619195

Krassilov, V. \& Schrank, E. (2011) New Albian macro- and palynoflora from the Negev (Israel) with description of a new 
gymnosperm morphotaxon. Cretaceous Research 32: 13-29.

http://dx.doi.org/10.1016/j.cretres.2010.10.001

Kunzmann, L., Mohr, B.A.R. \& Bernardes-de-Oliveira, M.E.C. (2009) Cearania heterophylla gen. nov. et sp. nov., a fossil gymnosperm with affinities to the Gnetales from the Early Cretaceous of northern Gondwana. Review of Palaeobotany and Palynology 158: 193-212.

http://dx.doi.org/10.1016/j.revpalbo.2009.09.001

Linnaeus, C. (1753) Species plantarum, exhibentes plantas rite cognitas, ad genera relatas, cum differentiis specificis, nominibus trivialibus, synonymis selectis, locis natalibus, secundum systema sexuale digestas. Holmiae: Impensis Laurentii Salvii. [1 May 1753]. 1200 p.

http://dx.doi.org/10.5962/bhl.title.669

Liu, H.-M., Ferguson, D.K., Hueber, F.M., Li, C.-S. \& Wang, Y.-F. (2008) Taxonomy and systematics of Ephedrites cheniae and Alloephedra xingxuei Ephedraceae. Taxon 57: 577-582.

Luerssen, C. (1879) Medicinisch-pharmaceutische Botanik. Handbuch der systematischen Botanik für Botaniker, Aerzte und Apotheker. Leipzig: Verlag von H. Haessel. Band II, Phanerogamen, Lief. 1. 80 Seiten mit 35 Holzschn. 160 p. http://dx.doi.org/10.1002/ardp.18792150472

Martius, C.F.P. Von (1835) Conspectus Regni Vegetabilis Conspectus regni vegetabilis: secundum characteres morphologicos praesertim carpicos in classes ordines et familias digesti, adjectis exemplis nominibusque plantarum usui medico technico et oeconomico inservientium - Uebersicht der Classen, Ordnungen und Familien des Gewächsreiches nach morphologischen Grundsätzen, unter besonderer Rücksicht auf den Fruchtbau, mit Angabe von Beispielen und von den in der Medicin, Technik und Oekonomie besonderswichtigen Pflanzen zunächst als Leitfaden bei seinen akademischen Vorlesungen entworfen von C. Fr. Ph. v. Martius. Nurnberg: Joh. Leonhard Schrag. 72p.

http://dx.doi.org/10.5962/bhl.title.7730

Martens, P. (1971) Les Gnétophytes. Berlin: Gebrüder Borntraeger. 295 p.

Miki, S. (1964) Mesozoic flora of Lycoptera beds in South Manchuria. Bulletin of the Mukogawa Women's University (Natural Science) 12: S13-S22.

Pax, F. (1894) Prantl's Lehrbuch der Botanik. Leipzig: Verlag Von Wilhelm Engelmsnn. 365p.

Pearson, H.H.W. (1929) Gnetales. Cambridge: Cambridge University Press. 194 p.

Price, R.A. (1996) Systematics of the Gnetales: a review of morphological and molecular evidence. International Journal of Plant Sciences 157:S40-S49.

http://dx.doi.org/10.1086/297402

Reveal, J.L. (1993) New ordinal names for extant vascular plants. Phytologia 74: 173-177.

Rothwell, G.W. \& Stockey, R.A. (2013) Evolution and phylogeny of Gnetophytes: evidence from the anatomically preserved seed cone Protoephedrites eamesii gen. et sp. nov. and the seeds of several Bennettitalean species. International Journal of Plant Sciences 174: 511-529. http://dx.doi.org/10.1086/668688

Rydin, C. \& Friis, E.M. (2010) A new Early Cretaceous relative of Gnetales: Siphonospermum simplex gen. et sp. nov. from the Yixian Formation of Northeast China. BMC Evolutionary Biology 10: 183. http://dx.doi.org/10.1186/1471-2148-10-183

Rydin, C., Pedersen, K.R., Crane, P.R. \& Friis, E.M. (2006a) Former diversity of Ephedra (Gnetales): evidence from Early Cretaceous seeds from Portugal and North America. Annals of Botany 98: 123-140.

Rydin, C., Pedersen, K.R. \& Friis, E.M. (2004) On the evolutionary history of Ephedra: Cretaceous fossils and extant molecules. Proceedings of the National Academy of Sciences of the United States of America 101: 16571-16576. http://dx.doi.org/10.1073/pnas.0407588101

Rydin, C., Wu, S.-Q. \& Friis, E.M. (2006b) Liaoxia Gnetales: ephedroids from the Early Cretaceous Yixian Formation in Liaoning, northeastern China. Plant Systematics and Evolution 262: 239-265. http://dx.doi.org/10.1007/s00606-006-0481-2

Stapf, O. (1889) Die Arten der Gattung Ephedra. Denkschriften der Kaiserlichen Akademie der Wissenschaften, Mathematisch? naturwissenschaftliche Klasse, Vienna 56: 1-112.

Stevenson, D.W. (1993) Ephedraceae. In Flora of North America Editorial Committee (eds.). Flora of North America North of Mexico, volume 2. New York: Oxford University Press. pp. 428-434.

Sun, G., Dilcher, D.L., Zheng, S.-L. \& Zhou, Z.-K. (1998) In search of the first flower: a Jurassic Angiosperm, Archaefructus, from Northeast China. Science 282: 1692-1695. http://dx.doi.org/10.1126/science.282.5394.1692

Sun, G., Zheng, S.-L., Dilcher, D.L., Wang, Y.-D. \& Mei, S.-W. (2001) Early angiosperms and their associated plants from western Liaoning, China. Shanghai: Shanghai Scientific and Technological Education Publishing House. 227 p.

Tao, J.-R. \& Yang, Y. (2003) Alloephedra xingxueii gen. et sp. nov., an early Cretaceous member of Epehdraceae from Dalazi Formation in Yanji Basin, Jilin Province of China. Acta Palaeontologica Sinica 42: 208-215.

Thomé, O.W. (1886) Flora von Deutschland: Österreich und der Schweiz in Wort und Bild für Schule und Haus. Gera: E. Köhler. Band 1. 366 p.

http://dx.doi.org/10.5962/bhl.title.5360

Wang, X. (2010) The Dawn Angiosperms. Heidelberg: Springer. 236p. 
Wang, X. \& Zheng, S.-L. (2009) The earliest normal flower from Liaoning Province, China. Journal of Integrative Plant Biology 51: 800-811.

http://dx.doi.org/10.1111/j.1744-7909.2009.00838.x

Wang, X. \& Zheng, S.-L. (2010) Whole fossil plants of Ephedra and their implications on the morphology, ecology and evolution of Ephedraceae Gnetales. Chinese Science Bulletin 55: 675-683.

http://dx.doi.org/10.1007/s11434-010-3069-8

Yabe, H. \& Endô, S. 1935. Potamogeton remains from the Lower Cretaceous? Lycoptera Beds of Jehol. Proceedings of the Imperial Academy 11(7): 274-276.

Yang, Y. (2007a) Asymmetrical development of biovulate cones resulting in uniovulate cones in Ephedra rhytidosperma (Ephedraceae). Plant Systematics and Evolution 264: 175-182. http://dx.doi.org/10.1007/s00606-006-0504-z

Yang, Y. (2007b) The nomenclature of fossil Ephedraceae. Taxon 56: 1271-1273. http://dx.doi.org/10.2307/25065920

Yang, Y. (2010) A review on Gnetalean macrofossils: problems and perspectives. Taiwania 55: 346-354.

Yang, Y., Geng, B.-Y., Dilcher, D.L., Chen, Z.-D. \& Lott, T.A. (2005) Morphology and affinities of an Early Cretaceous fossilEphedra archaeorhytidosperma sp. nov. (Ephedraceae) -Gnetopsida. American Journal of Botany 92: 231-241. http://dx.doi.org/10.3732/ajb.92.2.231

Yang, Y., Lin, L.-B. \& Wang, Q. (2013) Chengia laxispicata gen. et sp. nov., a new ephedroid plant from the Early Cretaceous Yixian Formation of western Liaoning, Northeast China: evolutionary, taxonomic, and biogeographic implications. $B M C$ Evolutionary Biology 13: 72. http://dx.doi.org/10.1186/1471-2148-13-72

Yang, Y. \& Wang, Q. (2013) The earliest fleshy cone of Ephedra from the Early Cretaceous Yixian Formation of Northeast China. PloS One 8(1): e53652. http://dx.doi.org/10.1371/journal.pone.0053652

Zhou, Z.-H., Barrett, P.M. \& Hilton, J. (2003) An exceptionally preserved Lower Cretaceous ecosystem. Nature 421: 807-814. http://dx.doi.org/10.1038/nature01420 